Acta Universitatis Wratislaviensis No 3798

PRAWO CCCXXIII

Wrocław 2017

DOI: $10.19195 / 0524-4544.323 .17$

\author{
ANDRZEJ BORKOWSKI \\ Uniwersytet Wrocławski \\ e-mail: andrzej.borkowski@uwr.edu.pl
}

\title{
Obrót nieruchomościami w Unii Europejskiej wobec swobody przepływu kapitału
}

1.

Jednolity rynek wewnętrzny Unii Europejskiej zapewnił, na niespotykaną nigdy wcześniej skalę, funkcjonowanie wspólnego obszaru gospodarczego bez granic wewnętrznych. Fundamentem wspólnoty są swobody przepływu towarów, usług i osób oraz kapitału, zawarte w traktatach, którym powszechnie przypisuje się charakter aktów konstytucyjnych porządku ponadnarodowego, cechującego się swoistą autonomią. Powoduje ona, że owe swobody stanowią ogólną podstawę instrumentalnej ingerencji w kształtowanie stosunków pomiędzy uczestnikami wspólnoty, państwami członkowskimi i Unią, władzą publiczną i jednostką, a w efekcie nie pozostają bierne wobec kształtowania sytuacji prawnej jednostki. Odrębność porządku prawnego Unii Europejskiej nie budzi dziś wątpliwości i jest poglądem dominującym w literaturze, potwierdzonym orzecznictwem Trybunału Sprawiedliwości Unii Europejskiej (wcześniej także ETS) ${ }^{1}$. Taki charakter prawa unijnego umożliwia występowanie jego różnorodnych powiązań z prawem państw członkowskich.

Rodzi się tu pytanie o miejsce tego prawa w porządku prawnym państw członkowskich i jego znaczenie dla działan konstytucyjnych organów tych państw, a co za tym idzie - o wpływ prawa unijnego na sytuację prawną jednostki (osoby fizycznej, prawnej i jednostki organizacyjnej bez osobowości prawnej, posiadającej zdolność prawną), w odniesieniu do realizacji swych uprawnień, wynikających z podstawowych swobód rynku wewnętrznego. To zagadnienie - z uwa-

1 Orzeczenie ETS 26/62, Van Gend an Loos v. Nederlandse Administratie der Belastingen, Zb. Orz. 1963; Orzeczenie ETS 16/64, Costa v. ENEL, Zb.Orz. 1964. 
gi na jego fundamentalne znaczenie dla funkcjonowania rynku — znalazło się w polu zainteresowań Trybunału Sprawiedliwości. Już wiele lat temu w orzecznictwie sformułowano, do dziś obowiązującą, zasadę pierwszeństwa (prymatu) prawa unijnego przed prawem państw członkowskich ${ }^{2}$.

Trybunał w sprawie Costa v. E.N.E.L. stwierdził, iż żadne przepisy prawa krajowego nie mogą przeważać nad prawem wywodzącym się z traktatu, będącym niezależnym źródłem prawa. Oznacza to, że zasada pierwszeństwa ma wobec norm prawa krajowego nieograniczony zasięg. Z pierwszeństwa korzystają bowiem wszystkie normy prawa unijnego, zawarte zarówno w prawie pierwotnym, jak i w wiążących aktach prawa pochodnego, co w konsekwencji powoduje, że zasada pierwszeństwa obejmuje swym zasięgiem wszystkie normy prawa krajowego ${ }^{3}$.

Jak stwierdza Stanisław Biernat, proklamowanie pierwszeństwa prawa Unii Europejskiej jest konsekwencją tezy o autonomicznym charakterze tego porządku prawnego. Państwa członkowskie, przyjmując traktat, ograniczyły swe kompetencje i stworzyły porządek prawny, który wiąże zarówno ich obywateli, jak i same państwa ${ }^{4}$. Stwierdzenie to ma odniesienie do sytuacji, gdy norm wewnętrznego porządku prawnego nie da się pogodzić z prawem unijnym w sprawach, w których występuje element transgraniczny. Jednocześnie uzasadniony wydaje się pogląd, reprezentowany w doktrynie, że zasada prymatu prawa unijnego nie narusza istoty zwierzchnictwa terytorialnego państwa członkowskiego ${ }^{5}$. Szczególnie gdy uwzględnić dziedziny regulacji prawnych, w odniesieniu do których państwa członkowskie zachowują wyłączność ${ }^{6}$. Niemniej jednak akty prawa wewnętrzne-

2 S. Biernat, Prawo Unii Europejskiej a prawo państw członkowskich, [w:] Prawo Unii Europejskiej, red. J. Barcz, Warszawa 2004, s. 234-236.

3 Linia orzecznicza ETS opowiada się (gdy idzie o szczegóły zagadnienia) za koncepcją pierwszeństwa stosowania prawa wspólnotowego, nie zaś za pierwszeństwem obowiązywania, co powoduje, że stwierdzenie przez sąd niezgodności prawa krajowego ze wspólnotowym nie wywołuje automatycznie utraty mocy obowiązującej (uchylenia) stosownej normy prawa krajowego. Takie stanowisko nie narusza przyjętych w prawie krajowym zasad eliminacji norm krajowych z porządku prawnego, co zazwyczaj leży w zakresie kompetencji sądów konstytucyjnych, por. wyrok Trybunału Sprawiedliwości z dnia 15 lutego 1964 r. w sprawie Flamino Costa v. E.N.E.L., 6/64, ECLI:C:1964:66.

${ }^{4}$ S. Biernat, op. cit., s. 239-240; M. Szydło, Podstawowe wolności gospodarcze, [w:] J. Grabowski, L. Kieres, A. Walaszek-Pyzioł, Publiczne Prawo Gospodarcze, „System Prawa Administracyjnego" 8a, Warszawa 2013, s. 68-69.

5 Por. R. Stefanicki, Ograniczenie swobodnego przeptywu ustug (kapitatu) usprawiedliwione względami interesu publicznego w świetle orzecznictwa Europejskiego Trybunału Sprawiedliwości, „Problemy Współczesnego Prawa Międzynarodowego, Europejskiego i Porównawczego” 3, 2005, s. 59. Trybunał Konstytucyjny w wyroku z dnia 11 maja 2005 r. w sprawie zgodności traktatu akcesyjnego z Konstytucją RP (sygn. k-18/04) kładzie szczególny nacisk na to, że Rzeczpospolita pozostaje państwem suwerennym, gdyż przekazała kompetencje Wspólnocie jedynie w niektórych sprawach, oraz że Wspólnoty — zgodnie z art. 5 ust. 1 Traktatu ustanawiającego Wspólnotę Europejską - mogą działać tylko w zakresie przewidzianym przez unormowania traktatowe.

${ }^{6}$ Por. art. 345 TFUE, na podstawie którego do porządku prawnego Unii Europejskiej wprowadzono klauzulę wyłączności prawa własności, zgodnie z którą traktaty nie określają zasad regulacji prawa własności w państwach członkowskich. 
go, stanowione w obszarach wyłącznych kompetencji krajowych, nie mogą pozostawać w sprzeczności z zasadami prawa unijnego, zaś państwa członkowskie, w materiach należących do ich kompetencji wyłącznych, swoje uprawnienia wykonują w zgodności z postanowieniami traktatu? ${ }^{7}$.

Niniejsze opracowanie ma na celu określenie treści i zakresu swobody przepływu kapitału wobec regulacji prawa krajowego państw członkowskich, uwzględniających formułę wymogów imperatywnych interesu publicznego.

\section{2.}

Prawo Unii Europejskiej uczyniło przedmiotem szczególnej ochrony swobodną cyrkulację towarów, osób, usług i kapitału. Swobodny przepływ kapitału, zdaniem wielu badaczy, stanowi warunek urzeczywistnienia podstawowych (pozostałych) swobód traktatowych ${ }^{8}$.

Nie wchodząc w szersze antecedencje kształtowania się swobody przepływu kapitału i płatności na wspólnym rynku europejskim ${ }^{9}$, wypada jedynie stwierdzić, że traktatową liberalizację obrotu osiągnięto dzięki postanowieniom Traktatu z Maastricht ${ }^{10}$. Traktat ten, wprowadzając pełną swobodę przepływu kapitału, uwzględnił możliwość odstępstwa i jej ograniczenia jedynie w przypadkach określonych w regulacji traktatowej ${ }^{11}$. Uczyniło to wolność przepływu kapitału jedną z podstawowych swobód rynku wewnętrznego ${ }^{12}$ Unii Europejskiej ${ }^{13}$. Postanowienia traktatu odnoszące się do tych swobód gwarantują przepływ transgraniczny

7 Por. A. Frąckowiak-Adamska, Obowiązek poszanowania prawa wspólnotowego w dziedzinach należących do kompetencji wyłącznych państw członkowskich, „Europejski Przegląd Sądowy" 3, 2005, s. 20.

${ }^{8}$ Por. K. Tomaszewski, Rynek wewnętrzny Unii Europejskiej - szansa i wyzwaniem obywateli, „Studia Prawnicze” 2003, nr 2, s. 117; M. Mataczyński, Swoboda przepływu kapitału a złota akcja Skarbu Państwa, Kraków 2007, s. 19-20.

9 Do zaawansowanej liberalizacji swobody przepływu kapitału przyczyniła się Dyrektywa Rady nr 88/361 z dnia 24 czerwca 1988 r. w sprawie wykonania art. 67 Traktatu (Dz.Urz. UEL 178 z dnia 8 lipca 1988 r.). Państwa członkowskie zostały zobowiązane do jej implementacji do 1 lipca 1990 r. Dyrektywa zobowiązywała państwa członkowskie do zniesienia ograniczeń w zakresie przepływu kapitału pomiędzy osobami zamieszkującymi terytorium jednego z państw członkowskich UE.

10 Dz.Urz. UEC 191 z dnia 29 lipca 1992 r.

11 Por. M. Mataczyński, Komentarz do art. 63 Traktatu o funkcjonowaniu Unii Europejskiej, [w:] Traktat o funkcjonowaniu Unii Europejskiej. Komentarz, t. 1, red. D. Mięsik, N. Półtorak, A. Wróbel, Warszawa 2012, s. 977 n.

12 Pojęcie „rynek wewnętrzny” używane jest w znaczeniu nadanym mu postanowieniem art. 14 ust. 2 TWE (dawny art. 8a ust. 2). Rynek wewnętrzny obejmuje obszar bez granic wewnętrznych, w obrębie którego zagwarantowany jest swobodny przepływ towarów, osób, usług i kapitału, zgodnie z postanowieniami niniejszego traktatu.

13 Por. M. Szpunar, Promocja towarów w prawie wspólnotowym, Kraków 2002, s. 15. 
sposób nakazujący państwom członkowskim znoszenie (eliminowanie) wszelkich ograniczeń (przeszkód) utrudniających nieskrępowane przemieszczanie towarów, osób, usług oraz kapitału. Wynika to jednoznacznie zarówno z brzmienia relewantnych postanowień traktatu, nakazujących znoszenie ograniczeń, jak i z licznych orzeczeń Trybunału Sprawiedliwości, w których wielokrotnie stwierdzał, że postanowienia traktatu dotyczące podstawowych swobód sprzeciwiają się stosowaniu przez państwa członkowskie regulacji, które mogą stanowić „przeszkodę” lub też „utrudnienie" w swobodnym przepływie ${ }^{14}$.

Dość powszechnie przyjmuje się, że chodzi tu o konkretne regulacje prawa krajowego oraz określone praktyki organów władzy publicznej, podejmujących czynności prawne zarówno w obszarze prawa publicznego, jak i prawa prywatnego, które nie pozwalają towarom, osobom lub kapitałowi swobodnie cyrkulować.

Wszystkie te regulacje i praktyki powodują segmentację (podzielenie) rynku wewnętrznego, sprawiając, że na rynku europejskim nie panują takie warunki jak na rynkach krajowych (państwa członkowskiego) ${ }^{15}$. Postanowienia traktatu odnoszące się do podstawowych swobód mają bowiem na celu eliminację tych działań państw członkowskich, które mogłyby skutkować niedopuszczalnym (nieusprawiedliwionym) ograniczeniem wolności.

Wobec sformułowanego w tytule przedmiotu opracowania szczegółowej analizie poddana zostanie swoboda przepływu kapitału, której regulacje traktatowe oraz linia orzecznicza Trybunału Sprawiedliwości determinują ustawodawstwo krajowe, odnoszące swe postanowienia do obrotu nieruchomościami w krajach członkowskich. Nie budzi wątpliwości, iż adresatami postanowień traktatowych dotyczących swobody przepływu kapitału są państwa członkowskie ${ }^{16}$. To one bowiem w obrębie swoich terytoriów dysponują właściwymi kompetencjami

14 Por. orzeczenia ETS m.in. w sprawach C-60/00, Mary Carpenter v. Secretary of State for the Home Department, Zb.Orz. 2002, s. I-6279, pkt 39-40; C-114/97, Komisja v. Hiszpanii, Zb.Orz. 1998, s. I-6717, pkt 44; C-221/89, The Queen v. Secretary of State gor Transport ex parte Factortame Ltd et al., Zb.Orz. 1991, s. I-3905, pkt 23; C-275/92, Her Majesty's Customs \& Excise v. Gerhard Schindler \& Jorg Schindler, Zb.Orz. 1994, s. I-1039, pkt 45.

15 Por. M. Szydło, Swoboda prowadzenia działalności gospodarczej i swoboda świadczenia ustug w prawie Unii Europejskiej, Torun 2005, s. 141 n.

16 W pojęciu ,państwa członkowskiego" na potrzeby interpretacji uregulowań TFUE w zakresie swobód rynku wewnętrznego należy ujmować wszystkie kategorie władz państwowych, a zatem władze ustawodawcze, wykonawcze oraz sądownicze. Por. wyrok TS z dnia 22 stycznia 1981 r. w sprawie 58/80, Dansk Supermarket A/S przeciwko A/S Imerko, Zb.Orz. 1981, s. 181, pkt 12. Oznacza to, że podmiotami zobowiązanymi do respektowania swobód są: parlamenty krajowe, stanowiące prawo powszechnie obowiązujące, wszelkiego rodzaju sądy oraz trybunały, dokonujące władczych czynności judykacyjnych, polegające na stosowaniu prawa w indywidualnych sprawach oraz organy wchodzące w skład szeroko rozumianej władzy wykonawczej. Por. M. Szydło, Podstawowe wolności gospodarcze..., s. 69. 
zwierzchnimi, umożliwiającymi im kreowanie barier utrudniających swobodną cyrkulację ${ }^{17}$.

Jak słusznie dowodzi Marek Szydło, to przysługujące państwom członkowskim prawo stanowienia przepisów normatywnych oraz kształtowania praktyki obrotu powoduje, że są one źródłem najpoważniejszych i najbardziej negatywnie odczuwalnych barier na rynku wewnętrznym Unii Europejskiej. Z drugiej zaś strony, to właśnie państwa członkowskie mogą owe - przez siebie stanowione — bariery eliminować (znosić) ${ }^{18}$.

$\mathrm{Z}$ postanowień art. 63 Traktatu o funkcjonowaniu Unii Europejskiej (dalej: TFUE) jednoznacznie wynika zakaz stosowania wszelkich ograniczeń odnoszących się do swobodnego przepływu kapitału i płatności między państwami członkowskimi oraz między państwami członkowskimi a państwami trzecimi. Stąd płynie zobowiązanie, adresowane do państw członkowskich, likwidacji wszelkich barier i przeszkód w obrębie swobodnej cyrkulacji kapitału. Potwierdza to orzecznictwo TS, który stwierdza, że inwestorzy, dokonując wyboru miejsca alokacji kapitału, mogą przyjmować uwarunkowania ekonomiczne jako podstawę swych decyzji z pominięciem obaw o istniejące $\mathrm{w}$ wybranym kraju członkowskim utrudnienia prawne $i$ administracyjne ${ }^{19}$.

$\mathrm{Z}$ punktu widzenia celu niniejszego opracowania istotne jest ustalenie treści swobody przepływu kapitału w interesującym nas zakresie. Określenie tej swobody pozwoli wyszczegółowić, na jakich zasadach osoba objęta zakresem podmiotowym swobody może w państwie przyjmującym (goszczącym) dokonać czynności (korzystać z uprawnień do ich dokonania) objętych zakresem przedmiotowym swobody.

Zasada, która jest treścią omawianej swobody, wyznaczać będzie minimalny poziom publicznoprawnych gwarancji, jakie w państwie goszczącym powinny być przyznane inwestorowi z tej swobody korzystającemu. $Z$ teoretycznego punktu widzenia zatem — w świetle poglądów doktryny oraz dorobku orzeczniczego Trybunału Sprawiedliwości - każda ze swobód rynku wewnętrznego, co oczywiście uwzględnia swobodę przepływu kapitału, może być oparta na określonych zasadach, wyznaczających sposób traktowania podmiotów z niej korzystających przez państwo członkowskie przyjmujące. Do podstawowych zasad zalicza się powszechnie: zakaz dyskryminacji, zakaz wszelkich ograniczeń, stanowiących przeszkodę w nieskrępowanym korzystaniu ze swobody oraz zakaz stosowania środków dublujących (powielających) warunki, które zostały spełnione przez uprawnionego w innym państwie rynku wewnętrznego.

17 Por. Prawo materialne Unii Europejskiej, red. A. Zawidzka-Łojek, R. Grzeszczak, Warszawa 2012, s. 177.

18 M. Szydło, Swoboda rynku wewnętrznego a reguly konkurencji. Między konwergencja a dywergencja, Torun 2006, s. 346-348.

19 Wyrok TS z dnia 18 grudnia 2007 r. w sprawie C-101/05, Skatteverket v. A., ECLI:EU: C:2007:804, pkt 21. 
Zakaz dyskryminacji oznacza, najogólniej rzecz ujmując, traktowanie podmiotu korzystającego ze swobody w państwie przyjmującym na zasadzie traktowania narodowego, przyznając mu te same prawa, lecz także te same obowiązki, których adresatem jest podmiot rodzimy ${ }^{20}$.

Zakaz stosowania środków dublujących wyznacza z kolei standard traktowania, określony jako reguła kraju pochodzenia, w myśl której niedopuszczalna jest dyskryminacja, a co więcej - nakładanie na zainteresowanego (inwestora) obowiązków, którym został już wcześniej poddany w innym państwie.

Najdalej ingerującym w swobodę państwa przyjmującego jest zakaz ogólny stosowania ograniczeń. Jest jednocześnie najdalej idącą formułą ochrony inwestora, chroniącą go przed każdą ingerencją, stanowiącą barierę w korzystaniu ze swobód na rynku wewnętrznym ${ }^{21}$. Nie obejmuje jednak stosowania środków mających uzasadnienie w ochronie doniosłych (nadrzędnych) dóbr chronionych, w szczególności porządku publicznego lub bezpieczeństwa publicznego ${ }^{22}$.

Sformułowany w art. 63 TFUE zakaz wszelkich ograniczeń swobody przepływu kapitału między państwami członkowskimi obejmuje też cyrkulację kapitału między nimi a państwami trzecimi. Taki zakres podmiotowy mieści w sobie także wyłączenia tej swobody, usprawiedliwione ważnym interesem publicznym. Owe wyłączenia, umożliwiające ograniczenie swobody przepływu, uwarunkowane są zastosowaniem środków prawnych niedyskryminacyjnych i pod warunkiem ich proporcjonalności wobec chronionego dobra.

Swoboda przepływu kapitału jako pojęcie prawne nie zostało w postanowieniach traktatu zdefiniowane. Nie zostało ono zdefiniowane jednoznacznie także w innych uregulowaniach prawa Unii Europejskiej. W doktrynie, uwzględniającej judykaturę, przyjmuje się, że jest to jednostronne przeniesienie wartości majątkowych w formie pieniężnej bądź rzeczowej w celu inwestycyjnym między — co najmniej — dwoma państwami członkowskimi lub między państwem członkowskim a państwem trzecim ${ }^{23}$.

Postanowienie art. 63 TFUE przyjmuje rozróżnienie na tzw. rzeczywisty przepływ kapitału oraz płatności bieżące, podlegające odrębnemu reżimowi prawnemu, który nie jest przedmiotem badawczym niniejszego opracowania. Przepływ kapitału (o charakterze inwestycyjnym) jest dokonywany w celu realizacji samoistnej inwestycji komercyjnych, przy użyciu środków lub instrumentów finansowych, z zachowaniem transgraniczności obrotu. Jednoznaczne określenie zakresu przedmiotowego przepływu kapitału ma szczególne znaczenie praktyczne dla realizacji wolności traktatowej, ponieważ tylko zakwalifikowanie określonej

20 M. Strzelbicki, Publicznoprawne gwarancje swobody świadczenia ustug przez podmioty wspólnotowe w Polsce, Poznań 2008, s. 55-60.

21 Ibidem, s. 60-61.

22 Por. art. 65 ust. 1 pkt b TFUE.

23 B. Bacia, A. Zawidzka, Swoboda przepływu kapitału i ustugi finansowe w Unii Europejskiej, „System Prawa Unii Europejskiej” 18, Warszawa 2011. 
aktywności kapitałowej (operacji) na rynku wewnętrznym jako przepływ kapitału umożliwia objęcie jej właściwą ochroną prawa unijnego.

Doniosła waga problemu spowodowała zainteresowanie Trybunału Sprawiedliwości ${ }^{24}$, który w sprawie zakresu przedmiotowego klasycznego przepływu kapitału uznał za uzasadnione sięgnięcie do dyrektywy nr 88/361, która w załączniku nazwanym „Nomenklatura do przepływu kapitału” ${ }^{25}$ zawiera katalog czynności wykonywanych przez nierezydentów w jednym z państw członkowskich oraz jego rezydentów za granicą, które uznaje się za przepływ kapitału. Pośród wymienionych czynności wskazane są: inwestycje bezpośrednie oraz inwestycje $\mathrm{w}$ nieruchomości. Z kolei uznanie transgraniczne obrotu nieruchomościami jako klasycznego przepływu kapitału kwalifikuje te czynności jako chronione traktatową swobodą przepływu kapitału. Innymi słowy, prawo wszystkich obywateli Unii Europejskiej do obrotu nieruchomościami położonymi na obszarze państw członkowskich $^{26}$ jest integralnym elementem swobody przepływu kapitału ${ }^{27}$.

\section{3.}

Uregulowania prawne odnoszące się do stosunków własnościowych, a w tym prawo własności nieruchomości, stanowią przedmiot regulacji wyłączony spod bezpośredniej legislacji Unii Europejskiej. W art. 345 TFUE została bowiem zawarta klauzula wyłączająca regulację prawa własności z unijnego porządku prawnego, co oznacza, że prawo Unii Europejskiej pozostawia regulację stosunków własnościowych w zakresie wyłącznych kompetencji właściwych organów państw członkowskich ${ }^{28}$. Stwierdzenie to odnosi się w szczególności do tworze-

${ }^{24}$ Wyrok ETS z dnia 16 marca 1999 r. w sprawie C-222/97, M. Tummer i P. Mayer, Zb.Orz. 1999, s. I-1661.

25 Dyrektywa została wydana do wcześniej obowiązujących przepisów TWE; nakazywała znoszenie ograniczeń w przepływie kapitału i stanowiła podstawę do zmian wprowadzonych Traktatem z Maastricht. Pomimo że przepisy, na podstawie których dyrektywa została uchwalona, przestały obowiązywać, jest ona nadal uznawana za wiążące źródło prawa - A. Cieśliński, Wspólnotowe prawo gospodarcze, Warszawa 2003, s. 341.

26 Uwzględniając postanowienia art. 355 TFUE, moc obowiązująca traktatów rozciąga się na terytoria objęte jurysdykcją państw członkowskich. Dotyczy zatem m.in. francuskich departamentów zamorskich, portugalskich Azorów i Madery oraz hiszpańskich Wysp Kanaryjskich.

27 Por. wyrok ETS z dnia 1 czerwca 1999 r. w sprawie C-302/97, Klaus Konle przeciwko Republika Austriacka, Zb.Orz. 1999, s. I-3099.

${ }^{28}$ Zob. wyrok Trybunału Sprawiedliwości (Wielka Izba) z dnia 22 października 2013 r. w sprawach połączonych Staad der Nederlanden przeciwko Essent MV (C-105/12), Essent Nederlanden BV (C-105/12), Eneco Holding NV (C-106/12) i Delta NV (C-107/12), pkt 21, 29. W pkt 29 Trybunał stwierdził: ,[a]rtykuł 345 TFUE wyraża zasadę neutralności traktatów wobec zasad prawa własności w państwach członkowskich”. Jednakże w pkt 36 przyjął, że ,art. 345 TFUE nie wyklucza zastosowania wobec zasad prawa własności obowiązujących w państwach członkowskich podstawowych 
nia przez system prawny państwa członkowskiego zasad kształtowania stosunków cywilno-prawnych pomiędzy podmiotami stosunków własnościowych.

W polskim systemie prawnym podstawowe znaczenie ma w tym zakresie zasada swobody umów, czyli kompetencji podmiotów do kształtowania stosunków zobowiązaniowych w drodze dwustronnych czynności prawnych. Podstawowym wyznacznikiem tej zasady jest swoboda wyboru kontrahenta oraz swoboda kształtowania treści stosunku zobowiązaniowego ${ }^{29}$.

Swoboda kontraktowa w polskim prawie zobowiązań jest ukształtowana według modelu tzw. kompetencji generalnej, co oznacza, że prawodawca ustanawia wolność kształtowania treści stosunków obligacyjnych, zakreślając jednocześnie w sposób ogólny jej granice ${ }^{30}$. Powszechnie uznaje się, że zasada (autonomii woli stron) swobody kontraktowej ma swoje aksjologiczne uzasadnienie w szeroko rozumianej wolności jednostki. Podkreśla się ponadto wagę tej reguły dla urzeczywistnienia zasad i wolności charakterystycznych dla społecznej gospodarki rynkowej ${ }^{31}$. Wywodzona z postanowień art. $353^{1}$ k.c. reguła, zgodnie z którą strony umowy kształtują stosunek prawny zgodnie ze swą wolą (według swego uznania), ograniczona jest stwierdzeniem „byleby jego treść lub cel nie sprzeciwiały się właściwości (naturze) stosunku, ustawie ani zasadom współżycia społecznego". Należy uznać, że w świetle powołanych postanowień k.c. swoboda umów nie ma charakteru absolutnego. Jej granice wyznaczone są poprzez naturę stosunku, ustawę szczególną, lecz także zasady współżycia społecznego, zaś przekroczenie (naruszenie) tych granic co do zasady sankcjonowane jest nieważnością czynności prawnej.

Z punktu widzenia niniejszego opracowania uzasadniona wydaje się bliższa identyfikacja ustawy jako podstawy ograniczenia swobody kontraktowej. Otóż nie ulega wątpliwości, iż ustawodawca używając określenia „ustawa”, odnosi je do wszystkich uregulowań, które w świetle postanowień art. 82 Konstytucji RP kwalifikowane są jako źródła prawa powszechnie obowiązującego, a zatem obok Konstytucji i ustaw — również ratyfikowanych umów międzynarodowych, a w określonym zakresie także aktów prawa miejscowego.

Prawo wewnętrzne kraju członkowskiego, regulując stosunki własnościowe obowiązujące na jego terytorium w trybie aktów stanowionych przez organy tego państwa, jest jednoznacznie zobowiązane do uwzględniania postanowień prawa

reguł TFUE, w tym w szczególności zasady niedyskryminacji [...] i swobody przepływu kapitału". Zob. podobne wyroki: z dnia 6 listopada 1984 r. w sprawie 182/83 Fearon, Rec., s. 3677, pkt 7; z dnia 1 czerwca 1999 w sprawie C-302/97, Konle, Rec., s. 3099, pkt 38; z dnia 21 grudnia 2011 r. w sprawie C-271/09, Komisja przeciwko Polsce, Zb.Orz. 2012, s. I-13613, pkt 44.

29 W. Czachórski et al., Zobowiązania. Zarys wykładu, Warszawa 2009, s. 145-146.

30 P. Machnikowski, Swoboda umów wedlug art. $353^{1}$ k.c. Konstrukcja prawna, Warszawa 2005, s. 6-15.

31 P. Machnikowski, [w:] Prawo zobowiąań - część ogólna, red. E. Łętowska, „System Prawa Prywatnego" 5, Warszawa 2006, s. 430. 
pochodzącego z ratyfikowanych umów międzynarodowych. Te ostatnie obejmują traktaty tworzące prawo wewnętrzne, pochodzące od prawodawcy unijnego. Jak wcześniej zaznaczono, te regulacje obowiązującego prawa zachowują prymat nad regulacjami wewnętrznymi. Powoduje to, że treść regulacji prawa wewnętrznego, również w sferze nieruchomości, uzależniona jest od postanowień traktatowych w taki sposób, że kształtowanie regulacji wewnętrznych może odbywać się w granicach określonych przez postanowienia traktatowe, z uwzględnieniem swobód rynku wewnętrznego. W rezultacie tą drogą prawo Unii Europejskiej wywiera zasadniczy wpływ na wykonywanie własności w państwach członkowskich ${ }^{32}$ pomimo formalnej autonomii wywodzonej w tym zakresie $\mathrm{z}$ art. 345 TFUE.

Nie oznacza to oczywiście bezwzględnego zakazu krajowych regulacji ograniczających nabywanie prawa własności nieruchomości przez cudzoziemców unijnych w państwach członkowskich. $Z$ postanowień art. 65 TFUE wynika bowiem jednoznacznie, iż zakaz ustanawiania ograniczeń w swobodzie przepływu kapitału nie nosi cech bezwzględności.

Dopuszczalność derogacji od wolności przepływu kapitału jest uwarunkowana przesłankami wynikającymi wprost $\mathrm{z}$ art. 65 TFUE oraz wywodzonymi z obszernego orzecznictwa Trybunału Sprawiedliwości. Środek krajowy stanowiący utrudnienie (przeszkodę) w swobodnym przepływie kapitału może być uznany za dopuszczalny (usprawiedliwiony), pod warunkiem że nie powoduje arbitralnej dyskryminacji ${ }^{33}$ ani ukrytego ograniczenia ${ }^{34}$ oraz jest zgodny z zasadą proporcjonalności i służy prawnie uzasadnionemu celowi, określonemu w art. 65 TFUE. Należy przy tym dodać, że usprawiedliwianie przez państwo członkowskie dokonanego naruszenia (derogacji) obowiązków wynikających ze swobody przepływu kapitału powoduje legalizację tego naruszenia, sprawiając, że staje się ono z punktu widzenia prawa unijnego - prawnie wiążące.

Jak wskazano powyżej, państwo członkowskie - chcąc usprawiedliwić, a w efekcie zalegalizować naruszenie obowiązków traktatowych odnoszących się do swobody przepływu kapitału — może się w tym celu powołać na dwie grupy dopuszczalnych prawem unijnym przyczyn. Pierwszą z nich stanowią przesłanki

32 Trybunał Sprawiedliwości w sprawie Klaus Konle v. Austria stwierdził jednoznacznie, że organizacja prawa własności należy do wyłącznej kompetencji państw członkowskich, lecz postanowienia art. 345 TFUE nie wyłączają obowiązku stosowania (uwzględnienia) fundamentalnych zasad traktatowych — wyrok TS z dnia 1 lipca 1999 r. w sprawie C-302/97, Klaus Konle v. Republik Ostereich, ECLI:C:1999:271.

33 Do barier dyskryminujących zalicza się kategorie przeszkód bezpośrednio bądź pośrednio (ukrycie) dyskryminujących. Dyskryminują one m.in. ze względu na obywatelstwo lub kryteria zawarte w art. 54 TFUE (siedziba) lub ze względu na to, czy dany proces gospodarczy ma charakter czysto wewnętrzny, czy transgraniczny.

34 Ograniczeniem ukrytym, niedyskryminującym są przeszkody wynikające z działań podmiotów zobowiązanych (państwa członkowskich), które nie dyskryminują wprost, jednakże stanowią przeszkody w dostępie do rynku państwa alokacji inwestycji, hamują lub czynią ten rynek mniej atrakcyjnym poprzez zniechęcanie inwestorów. 
wyspecyfikowane w samym traktacie. Drugą — szerokie spektrum dóbr chronionych oraz wartości wyższego rzędu, ogólnie określanych mianem imperatywnych wymogów interesu publicznego ${ }^{35}$.

\section{4.}

W poszukiwaniu kompromisu pomiędzy koniecznością budowy (utrzymania) zintegrowanego rynku wewnętrznego a ochroną uzasadnionego interesu państw członkowskich fundamentalne znaczenie ma orzecznictwo Trybunału Sprawiedliwości. Szczególnie zaś, wskazana wyżej, wypracowana przez Trybunał formuła wymogów imperatywnych ${ }^{36}$ interesu publicznego. Stwarza ona po stronie państw członkowskich możliwość ustanowienia środków krajowych, ograniczających swobodę rynku wewnętrznego, uzasadnionych (usprawiedliwionych) ochroną ważnych względów interesu ogólnego. Konieczność urzeczywistnienia wartości interesu ogólnego może zatem stanowić usprawiedliwienie dla dokonania przez państwo członkowskie naruszenia obowiązku wynikającego ze swobody rynku wewnętrznego, przy czym, aby owo usprawiedliwienie mogło zostać przez unijny porządek prawny zaakceptowane (co w konsekwencji zalegalizuje dokonane naruszenie), musi spełniać dodatkowe warunki ${ }^{37}$.

Najistotniejszym z nich jest przestrzeganie przez zobowiązane państwo zasady proporcjonalności. Jest ona podstawowym kryterium oceny prawa stanowionego przez państwo członkowskie, ograniczającego w imię interesu publicznego swobodę przepływu kapitału. Zasada proporcjonalności wymusza na państwach członkowskich racjonalność działań podejmowanych w ramach wymogów imperatywnych interesu publicznego. Owa racjonalność oznacza przede wszystkim obowiązek podejmowania właściwych środków z poszanowaniem uporządkowanego systemu wartości wspólnotowych oraz uwzględnienie i ważenie wszystkich interesów w sposób odpowiednio proporcjonalny do uzyskanych korzyści interesu ogólnego. Chodzi o to, aby podejmowane środki były prawnie uzasadnione, właściwe i konieczne do osiągnięcia zamierzonego celu, natomiast gdy istnieje moż-

35 M. Szydło, Podstawowe wolności gospodarcze..., s. 77-78. Autor zwraca uwagę, że w orzecznictwie oraz literaturze przedmiotu obok określenia „imperatywne wymogi interesu publicznego" występuje wymiennie pojęcie ,imperatywne względy interesu publicznego" i „,konieczne wymogi interesu publicznego"; zob. też K. Milecka, Wymogi imperatywne interesu ogólnego a swoboda przepływu towarów - przykład wybranych orzeczeń Trybunatu Sprawiedliwości UE z lat 2006-2009, [w:] Iustitia est constans et perpetua voluntas ius summ cuique trineundi, red. J. Pakuła, A. Pikulik, Torun 2011, s. 359-372.

36 A. Zawidzka, Rynek wewnętrzny Wspólnoty Europejskiej a interes publiczny, Warszawa 2002, s. 19 oraz powołane tam orzecznictwo, m.in. Cassis de Dijon, sprawa 120/78, Rewe v. Bundesmonopolverwaltung fur Branntwein [1979] ECR649.

37 M. Szydło, Podstawowe wolności gospodarcze..., s. 79. 
liwość wyboru pomiędzy różnymi środkami, należy stosować ten, który stanowi najmniejszą uciążliwość dla inwestora ${ }^{38} \mathrm{i}$ wykazuje najniższą represyjność ${ }^{39}$.

Uprawniony jest pogląd prezentowany $\mathrm{w}$ doktrynie, iż zasada proporcjonalności jest instrumentem ochrony rynku wewnętrznego UE, zapobiegającym ustanowieniu przez państwa członkowskie przeszkód w realizacji swobód wspólnotowych, jednocześnie chroniącym beneficjentów tych swobód przed nieuzasadnioną (nadmierną) ingerencją państw członkowskich ${ }^{40}$. Takie stanowisko potwierdza orzecznictwo Trybunału Sprawiedliwości, który odnosząc się do zastosowania formuły wymogów imperatywnych w obrocie nieruchomościami, uznał dopuszczalność ograniczeń ustanowionych przez państwa członkowskie (utrudniających realizację swobody przepływu kapitału) w ramach tej formuły, jednak pod warunkiem ich powszechności, co oznacza, że przepisy krajowe muszą być adresowane do wszystkich podmiotów, potencjalnych inwestorów — nigdy w sposób wybiórczy i dyskryminujący. Ponadto powinny być adekwatne (właściwe) dla osiągnięcia celu, któremu służą, nie mogą być zatem nadmiernie uciążliwe wobec zakładanego celu ${ }^{41}$.

\section{5.}

Konkludując, należy stwierdzić, iż z dorobku orzecznictwa Trybunału Sprawiedliwości odnoszącego się do swobody przepływu kapitału, z uwzględnieniem swobody obrotu nieruchomościami, wynika możliwość stosowania przez kraje członkowskie regulacji prawa wewnętrznego. Przepisy krajowe, z których postanowień wynikają ograniczenia dla swobody przepływu kapitału, uzyskują skuteczność prawną w odniesieniu do cudzoziemców unijnych wyłącznie w przypadku wyraźnej podstawy prawnej umożliwiającej utrudnienie obrotu, wynikającej z obowiązującego prawa zawartego w traktatach (katalog zamknięty) lub w wypadku powołania się na formułę wymogów imperatywnych interesu publicznego (katalog otwarty). Aby zakwalifikować krajowe utrudnienia przepływu jako usprawiedliwione w świetle wymogów imperatywnych, nie mogą one być regulacjami dyskryminującymi. Muszą za to być stanowione zgodnie z zasadą proporcjonalności i jednocześnie służyć szczególnemu, prawnie uzasadnionemu celowi

38 Por. wyrok TS z dnia 13 listopada 1990 r. w sprawie C-331/88, The Queen v. Minister of Agriculture, Fisheries and Food and Secretary of State for Health, ECLI:EU:C:1990:391, pkt 13.

39 J. Maliszewska-Nienartowicz, Zasada proporcjonalności w prawie Wspólnot Europejskich - kryteria i zakres kontroli dokonywanej przez Trybunat Sprawiedliwości, [w:] Zasady ogólne prawa wspólnotowego, red. C. Mik, Torun 2007, s. 256-257.

40 J. Maliszewska-Nienartowicz, Zasada proporcjonalności w prawie Wspólnot Europejskich, Toruń 2007, s. 91.

41 Wyrok TS z dnia 4 czerwca 2002 r. w sprawie C-367/98, Komisja Wspólnot Europejskich przeciwko Republice Portugalskiej, Zb.Orz. 2002, s. I-04731. 
interesu publicznego. Cel ten powinien odnosić się do szeroko rozumianego dobra publicznego i nie może mieć wyłącznie charakteru ekonomicznego.

W dotychczasowym orzecznictwie Trybunał Sprawiedliwości uznał za dopuszczalne (usprawiedliwione) regulacje krajowe ograniczające swobodę obrotu nieruchomościami w obrębie rynku wewnętrznego UE, powołujące się na racjonalne wykorzystanie gruntów rolnych ${ }^{42}$ i rozwój gospodarstw rolnych, wymóg zagospodarowania przestrzennego ${ }^{43}$ oraz utrzymania stałej populacji, trudniącej się działalnością poza sektorem turystyki ${ }^{44}$, uznając te powody za przesłanki imperatywne interesu publicznego.

Elastyczny charakter formuły wymogów imperatywnych umożliwia państwom członkowskim stosowanie prawnych, usprawiedliwionych wskazanymi przesłankami, regulacji chroniących ich interes ogólny, przy uwzględnieniu (wyważeniu) interesu ogólnego Unii Europejskiej. Potrzeba uelastycznienia prawa w tym obszarze jest wynikiem doświadczenia wielu lat regulacji prawnych, odnoszących się do obrotu nieruchomościami z udziałem cudzoziemców, obowiązujących w krajach członkowskich UE. Restrykcyjny niekiedy charakter tych uregulowań jest akceptowany przez system prawny UE ze względu na szczególne potrzeby ochrony niektórych obszarów, ze swej natury lub położenia geograficznego, wykazujących wyjątkową atrakcyjność. Podobnie w odniesieniu do gruntów rolnych i lasów, ze względu na ich ograniczony zasób, którego państwo nie jest w stanie powiększyć.

42 Wyrok TS z dnia 23 września 2003 r. w sprawie C-452/01, Margarethe Ospelt i Schlosse Weissenberg Familienstifgtung, ECLI:EU:C 2003:493. W odpowiedzi na postawione pytanie prejudycjalne Trybunał uznał, że przepisy ograniczające obrót gruntami rolnymi i leśnymi są przedmiotem ochrony swobody przepływu kapitału. Orzekł, iż ograniczenie obrotu tymi gruntami może zostać uznane za dopuszczalne w świetle doktryny wymogów imperatywnych, jeżeli przepisy krajowe w sposób niedyskryminujący służyłyby celowi publicznemu i byłyby zgodne z zasadą proporcjonalności. Interes publiczny w rozstrzyganej sprawie uzasadniony był ochroną ludności wiejskiej, utrzymaniem odpowiednich warunków egzystencji, rozwojem gospodarstw rolnych oraz zachowaniem przestrzeni i krajobrazu, a w końcu zapobieganiem nadmiernej koncentracji własności gruntów rolnych i racjonalnemu ich wykorzystaniu. Jednocześnie Trybunał uznał za niedopuszczalny wymóg osobistego prowadzenia gospodarstwa rolnego przez nabywcę gruntu rolnego. Przekroczeniem wymogu proporcjonalności, zdaniem Trybunału, jest także wymóg prowadzenia gospodarstwa przez nabywcę w miejscu zamieszkania. Dlatego regulacje krajowe zostały uznane przez Trybunał za przekraczające wymogi ochrony interesu publicznego.

43 Wyrok TS z dnia 5 marca 2002 r. w sprawach połączonych C-515/99, C-519/99 do C-524/99, Hans Reisch i inni v. Burgermeister der Landeshauptstadt Salzburg $i$ Grundverkehrsbeauftrager des Landes Salzburg $i$ Anton Lassacher $i$ inni, ECLI:EU:C:2002:135. Trybunał uznał za uzasadnione ograniczenie usprawiedliwione względami zagospodarowania przestrzennego. Jednocześnie wskazał, że jest to możliwe, tylko jeżeli prawo krajowe nie ma charakteru dyskryminacyjnego oraz jest zgodne z zasadą proporcjonalności.

44 Wyrok TS z dnia 1 lipca 1999 r. w sprawie C-302/97, Klaus Konle v. Austria, ECLI:EU:C: 1999:271. W niniejszym wyroku Trybunał stwierdził, iż utrzymanie na danym obszarze kraju stałej populacji i struktury zatrudnienia oraz aktywności gospodarczej, niezwiązanej z sektorem turystycznym, może stanowić przesłankę wymogu imperatywnego interesu publicznego. 


\title{
Real property trade in the European Union and free movement of capital
}

\begin{abstract}
Summary
The subject matter of this article is to selectively discuss the basic factors affecting the freedom of real property trade within the common market of the European Union. The guaranties securing the freedom to acquire by union foreigners real property in the member states follow directly from the provisions of TFEU. The set of treaty regulations relating to internal market freedoms holds a key role in the process of realising the fundamental purposes of the European Union. The free movement of capital has profound meaning for the realisation of all the treaty freedoms. Deviations from the rule, which allow for limiting the freedom and which result from the will of the member states, are acceptable within the legal system of the European Union only in exceptional circumstances provided by that law. There are two groups of conditions required for a lawful deviation from the rule of the free movement of capital. The first group covers the considerations resulting directly from the Treaty. The second includes the circumstances deemed lawful pursuant to the formula of imperative requirements of the public interest.
\end{abstract}

Keywords: real property trade, free movement of capital, European Union, internal market, common market. 